\title{
Internet plus Law: Opportunities and Challenges of Chinese College Students' Legal Education
}

\author{
Ting Shan \\ Department of Law and Political Science, North China Electric Power University, Baoding, China, \\ 071000
}

1141440430@qq.com

Keywords: College students' legal education; “Internet plus”; Network supervision

\begin{abstract}
Because of the rapid development of information technology, The Internet has been very popular and "Internet plus" has become one of the most popular mode of development. On the other hand, because of the current legal education of college students has problem in all aspects, Its development is in a dilemma. Facing dilemma, the "Internet plus law" development mode has brought opportunities for Chinese college students' legal education, also it can take advantage of the characteristics of the Internet and promote the new development of China's college students' legal education. But just like every coin has two sides, the Tempting and false information on the Internet is also a big challenge for college students who are still immature. Therefore, developing Chinese college students' legal education through the "Internet plus law" mode, we should avoid its weaknesses and make full use of various media platform, strengthen network supervision, improve college students' self-control. Through the above methods, We can achieve the goal of developing the legal education in China.
\end{abstract}

\section{Introduction}

With the development of our country, social relationships become more and more complicated. Law as a social protection network, the demand for strengthening the construction of law is urgent. On the other hand, as the college students are considered as the future builders of society, strengthening their legal education is particularly important. However, due to various reasons, there are many problems in college students' legal education in our country. With the development of the Internet, many traditional industries are trying to combine with the Internet, and burst out a strong vitality, which also provides an excellent opportunity for college students' legal education. Some Chinese scholars in our country have made some research on this, but it is one-sided. And in the present situation, we will take "Internet plus law" as the breakthrough point, analysis opportunities and challenges of Chinese college students' legal education, find solutions to Chinese college students' legal education, and provide a reference for the legal education of college students in china.

\section{Current Situation of College Students' Legal Education}

College students are the future builders of our country, to strengthen their legal education is particularly important. However, due to various reasons, the current college students' legal education in our country, whether it is on campus or off campus, has many problems.

Imperfect Legal Education in Colleges. Chinese college students are lack of legal literacy and legal awareness, which has a close relationship with the university students' legal education.

The course of legal education in colleges is insufficient. In the course of related legal education, most of the legal education courses in colleges are few, almost only <Ideological and moral cultivation and legal basis> course is to college students. This course mainly introduces basic principles and legal concepts, involving almost all legal professional courses. its content is not easy to understand and is difficult to arouse the interest and enthusiasm of students' learning.

In the course of legal education, most lecturers are not legal professionals, and will naturally difficult to explain the problem clearly, which is not conducive to the University college students to accept and understand the legal knowledge. 
The Lack of Legal Education outside School. At present, legal publicity activities in our country have no practical effect in many cases. The legal publicity on society mainly rely on government leadership, and some local officials carry out this activities seriously which led to the current lack of legal publicity in the society.

In addition to the legal publicity, the current atmosphere of the rule of law in China is also inadequate. Due to the rapid development of China's economy, people pay more attention to the pursuit of material and ignore the spiritual cultivation and the most obvious manifestation is the current prevalence of money worship. In such a social environment, the rule of law atmosphere is Inadequate naturally.

\section{"Internet plus Law" Brought Opportunities to College Students' Legal Education}

In the information age, with the rapid development of the Internet, "Internet plus" has led to a number of traditional industry recovery. It created a lot of development miracle, and "Internet plus natural law" has become a new approach for the development of College Students' legal education.

The Openness of the Internet Helps to Reduce the Resistance of College Students' Legal Learning. The development of the Internet makes it possible for people to study at any time. Due to the openness of the Internet, university students find the relevant legal knowledge is more convenient and the information is more abundant than the traditional legal learning ways. In the information age, because of the openness of the Internet, students can break the limitation of time and space when studying legal knowledge. The Internet has greatly reduced the resistance of College Students' legal learning, and facilitated the legal learning of college students.

The Interactive Nature of the Internet Can Improve the Participation of College Students in Law Learning. One of the characteristics of the Internet is interactive. As the current variety of social software is endless, it is not difficult for college students to communicate on the Internet. This feature emphasizes the participation of college students and its equality. Through this characteristics, we can improve the participation the degree of College students.

\section{"Internet plus Law" Brought Challenges to College Students' Legal Education}

Everything has two sides, the Internet is no exception. Although the Internet makes many traditional industries revitalized, there are also many drawbacks. The rise of the Internet but for decades, as a new thing, the country is still a lack of effective regulation. Due to the openness of the Internet, in the storage of huge information at the same time, a variety of false information is also full of network. For the false information in the network, because of its huge number and the anonymity of the Internet, it is difficult to determine the location of the publication of false information, not to mention its punishment. What's more, because the media is still not mature, and the supervision is not in place, numerous media managers contrary to professional ethics and mislead the legal awareness of college students just for their own interests. This is very detrimental to the correct legal awareness of College students.

\section{In the "Internet plus Law" Mode, Way to Develop College Students' Legal Education}

Combine the Traditional Legal Education in Colleges with the Internet. Open online courses in legal education. With the development of information technology, open network course is no longer a dream. Network open course is a kind of online learning mode with interactive function, which breaks the limitation of the time and space of the traditional education, and makes the educational resources of the world to be shared.

Strengthening the construction of network in Colleges, creating a legal learning environment. Colleges should have their own campus website, and it should set the legal knowledge in special sections on the site, to solve legal problems. And Colleges also should create a good legal learning environment, so that students will learn the law as a habit, and ultimately promote the development of College Students' legal education.

To Improve the Relevant Issues of the Internet. Strengthen network supervision, and making 
network law. The network environment is not healthy, largely because of China's network supervision is not in place. Because of the lack of strong rules to regulate the illegal behavior, it is difficult to accurate qualitative in network illegal acts, and illegal personnel have nothing to fear because of our legal loopholes. Therefore, in the current rapid development of information technology the era, China should develop network laws as soon as possible, and strengthen the supervision of the internet.

Strengthen College Students' Legal Literacy, Regulate Their Network Behavior. In the use of the Internet to learn legal knowledge, students should also pay attention to resist the temptation of network. Due to the hidden nature of the network, network crime is rampant. College students in the face of cyber-crime should have legal awareness, pay attention to protect their own rights and interests. At the same time, we should also note that it is easy to improve their self-control, and in the face of the enormous benefits of cyber-crime, don't forget the beginning of the heart, and not reduced to a network of crime.

\section{Conclusion}

At present, there are many shortcomings in China's legal education of college students, and the curriculum is not reasonable, it is difficult to arouse students' interest and other issues are important factors that hinder the development of College Students' legal education in China. Colleges are at a loss what to do. "Internet plus" as a new model of development has brought opportunities for the development of China's legal education of college students. But in the use of the Internet to promote the development of Chinese college students' legal education, we should also pay attention to the Internet its own drawbacks, make full use of new media platform, and promote the new development of Chinese college students' legal education.

\section{References}

[1] He Songlan, Zhang Zengyong. Discussion on the Status Quo of Legal Education of College Students and the Way to Improve It [J]. Legal System and Society, 2012,15:160-161. (In Chinese)

[2] Zhu Yingying, Liu Jijun. Analysis on the Problems and Countermeasures of the Current Legal Publicity and Education Work [J]. Legality Vision(a), 2013,11:142+91. (In Chinese)

[3] Zhou Hanhua. On Internet Law [J]. China Legal Science, 2015,03:20-37. (In Chinese)

[4] Wu Zhipan. The Rise of "Internet Plus" and the Lag of Law [J]. Journal of Chinese Academy of Governance, 2015, 03:39-43. (In Chinese)

[5] Zhang Ping. Discussion on Some Problems of Internet Legal Regulation [J]. Intellectual Property, 2012, 08:3-16+2. (In Chinese)

[6] Liu Chengwei. The Opportunities and Challenges of "Internet Plus Law" [J]. Chinese Lawyer, 2016, 01:43-45. (In Chinese)

[7] Zhao Guoqing. "Internet plus Education": Opportunities, Challenges and Countermeasures [J]. China Awards for Science and Technology, 2015, 08:39-41. (In Chinese)

[8] Wang Fengmei. "Internet plus Legal Services Needs Professional Air [J]. Law \& Life, 2016, 01:18-19. (In Chinese)

[9] Cha Yide. The Risk of the Lack of Legal Education in College Students [J]. Journal of Luohe Vocational Technology College, 2008, 03:119-120. (In Chinese)

[10]Ouyang Qingfang, Shao Linghong. On the Scientific Education of College Students' Legal Education [J]. The Party Building and Ideological Education in Schools, 2012, 36:41-42. (In Chinese) 